\title{
Pengembangan Aplikasi Algoritma Genetika Berbasis Vba Excel Untuk Menyelesaikan Travelling Salesman Problem (Contoh Kasus: Tsp 20 Kota Di Rusia)
}

\author{
Ekra Sanggala \\ D4 Logistik Bisnis, Politeknik POS Indonesia \\ ekrasanggala@mail.ru
}

\begin{abstract}
Genetic Algorithm is a search process based on heuristic that can be used for various optimization problems. The Genetic Algorithm has several steps, including Parameter Settings, Initialize Population, Crossover, Mutation, Genotype-phenotype Mapping, Fitness, Selection and Termination. One way to explain these steps is using an application. Visual Basic Application for Excel (VBA Excel) can be used to create this application. The created application will explain the steps of Genetic Algorithm in solving TSP 20 Russian Cities. Although this time the created application fits only on practice and training, it still can be upgraded.
\end{abstract}

Keywords: Genetic Algorithm, VBA Excel, Application, TSP

\begin{abstract}
Abstrak
Algoritma Genetika merupakan proses pencarian dengan pendekatan heuristik yang dapat digunakan pada berbagai macam permasalah optimasi. Algoritma Genetika mempunyai beberapa tahapan, antara lain Setting Parameter, Initialize Population, Crossover, Mutation, Genotype-phenotype Mapping, Fitness, Selection dan Termination. Salah satu cara untuk menjelaskan tahapan-tahapan tersebut adalah dengan menggunakan aplikasi. Visual Basic Application for Excel (VBA Excel) dapat digunakan untuk membuat aplikasi ini. Aplikasi yang dihasilkan akan menjelaskan tahapan-tahapan Algoritma Genetika dalam menyelesaikan kasus TSP 20 Kota di Rusia Walaupun aplikasi ini hanya cocok untuk keperluan latihan dan sebagai media pembelajaran, aplikasi ini masih dapat dikembangkan lagi.
\end{abstract}

Kata kunci: Algoritma Genetika, VBA Excel, Aplikasi, TSP

\section{Pendahuluan}

Algoritma Genetika merupakan proses pencarian dengan pendekatan heuristik yang dapat digunakan pada berbagai macam permasalahan optimasi. Fleksibilitas Algoritma Genetika membuat algoritma ini banyak digunakan untuk menyelesaikan masalah-masalah optimasi. Evolusi merupakan dasar dari Algoritma Genetika. Keragaman spesies saat ini dan kesuksesan mereka untuk bertahan hidup merupakan sebuah alasan baik untuk mempercayai kekuatan dari evolusi. Spesiesspesies mempunyai kemampuan untuk beradaptasi dengan lingkungan mereka. Mereka berkembang menjadi struktur yang komplek yang memungkinkan mereka bertahan hidup di berbagai macam lingkungan. Perkawinan dan menghasilkan keturunan merupakan prinsip utama dari suksesnya proses evolusi. Hal-hal ini merupakan alasan yang baik untuk mengadopsi prinsipprinsip evolusi pada penyelesaian masalah-masalah optimasi [3].

Secara umum tahapan-tahapan yang terdapat pada Algoritma Genetika adalah sebagai berikut ini [3]:

1. Setting Parameters.
2. Initialize Population.

3. Crossover.

4. Mutation.

5. Genotype-phenotype Mapping.

6. Fitness.

7. Selection.

8. Termination.

Tahapan-tahapan ini yang menjadi dasar penulis untuk mengembangkan aplikasi yang dapat menjelaskan secara baik tahapan-tahapan tersebut. Salah satu permasalahan yang sering diselesaikan dengan menggunakan Algoritma Genetika adalah Travelling Salesman Problem (TSP) [1]. Dengan demikian penyelesaian TSP dapat dijadikan sebagai contoh bagaimana Algoritma Genetika bekerja. TSP merupakan permasalahan penentuan rute terpendek yang diawali dari titik start untuk mengunjungi sekumpulan titik tepat sekali dan diakhiri dengan kembali ke titik start [4].

Penggunaan Microsoft Office Excel dapat memberi kemudahan dan kenyamanan dalam melakukan berbagai perhitungan [2]. Excel menampilkan hasil perhitungan dalam bentuk spreadsheet sehingga tahapan-tahapan perhitungan dapat lebih mudah dipahami [5]. Dengan 
keunggulan Excel dari sisi tampilan ini, diharapkan dapat memberi kemudahan bagi para pembaca untuk memahami bagaimana Algoritma Genetika bekerja dalam menyelesaikan permasalahan TSP.

Visual Basic Application (VBA) merupakan salah satu aplikasi scripting language terbaik dari Microsoft, dan $V B A$ ini terdapat pada aplikasi Microsoft Office. Bahasa BASIC mendapatkan respek di tahun 1991 ketika Microsoft meluncurkan Visual Basic (VB) untuk sistem operasi Windows. VB membantu para programmer untuk mengembangkan aplikasi pada sistem operasi Windows. $V B$ inilah yang menjadi dasar dari $V B A[6]$.

Kombinasi antara $V B A$ dengan Excel menjadi sebuah alat yang sangat baik. Ada sekitar 400 juta orang yang menggunakan Microsoft Office dan sebagian besar tidak memahami bagaimana memanfaatkan kehebatan $V B A$ Excel. Dengan menggunakan $V B A$, tugas-tugas kita dalam Excel dapat diselesaikan lebih cepat. Jika menggunakan Excel untuk menyelesaikan tugas-tugas rutin, kita dapat menggunakan $V B A$ untuk menyelesaikannya hanya dalam beberapa detik [7]. Dengan memanfaatkan keunggulan dari VBA Excel ini, tahapan-tahapan pada Algoritma Genetika dapat dilakukan secara terprogram, sehingga tahapan-tahapan tersebut dapat diselesaikan jauh lebih cepat dibandingkan jika diselesaikan dengan Excel saja.

Tentunya akan terasa tidak lengkap jika aplikasi yang dihasilkan tidak disertai contoh penggunaannya. Oleh karena itu, penulis akan menggunakan "TSP 20 Kota di Rusia" sebagai permasalahan TSP yang akan diselesaikan menggunakan aplikasi tersebut. Tidak ada alasan ilmiah yang dapat menjelaskan mengapa TSP tersebut terpilih sebagai contoh yang akan digunakan, satu-satunya alasan pemilihan TSP tersebut adalah karena penulis pernah menimba ilmu di Rusia.

\section{Metode Penelitian}

Langkah-langkah dalam penelitian ini adalah sebagai berikut ini:

1. Menentukan 20 kota di Rusia yang akan dijadikan permasalahan TSP.

2. Menghitung jarak antara setiap kota.

3. Membuat Algoritma Genetika yang sesuai dengan permasalahan TSP.

4. Mengembangkan aplikasi berbasis VBA Excel untuk menjalankan Algoritma Genetika yang telah dibentuk.

5. Menggunakan aplikasi yang dihasilkan untuk menyelesaikan permasalahan TSP yang telah ditentukan.

\subsection{Penentuan 20 Kota di Rusia}

20 kota di Rusia yang akan dijadikan permasalahan TSP adalah ibu kota, Moskwa dan 19 kota dengan jumlah penduduk terbanyak. Maka berdasarkan data yang diperoleh dari https://www.geonames.org/ 20 kota yang terpilih adalah sebagai berikut ini:

1. Moskwa (Latitude: 55,75222; Longitude: 37,61556; Population: 10.381.222).

2. Saint Petersburg $(59,93863 ; 30,31413 ; 5.028 .000)$.

3. Novosibirsk $(55,04150 ; 82,93460 ; 1.419 .007)$.

4. Yekaterinburg $(56,85190 ; 60,61220 ; 1.349 .772)$.
5. Nizhniy Novgorod (56,32867; 44,00205; 1.284.164).

6. Samara $(53,20007 ; 50,15000 ; 1.134 .730)$.

7. Omsk $(54,99244 ; 73,36859 ; 1.129 .281)$.

8. Kazan $(55,78874 ; 49,12214 ; 1.104 .738)$.

9. Rostov-na-Donu (47,23135; 39,72328; 1.074.482).

10. Chelyabinks $(55,15402 ; 61,42915 ; 1.062 .919)$.

11. Ufa $(54,74306 ; 55,96779 ; 1.033 .338)$.

12. Volgograd (48,71939; 44,50183; 1.011.417).

13. Perm $(58,01046 ; 46,00861 ; 863.725)$.

14. Krasnoyarsk $(56,01839 ; 92,86717 ; 927.200)$.

15. Saratov $(51,54056 ; 46,00861 ; 863.725)$.

16. Voronezh $(51,67204 ; 39,18430 ; 848.752)$.

17. Tol'yatti $(53,53030 ; 49,34610 ; 702.879)$.

18. Krasnodar $(45,04484 ; 38,97603 ; 649.851)$.

19. Ulyanovsk $(54,32824 ; 48,38657 ; 640.680)$.

20. Izhevsk $(56,84976 ; 53,20448 ; 631.038)$.

\subsection{Menghitung Jarak Antara Setiap Kota}

Untuk menghitung jarak antara setiap kota ini digunakan Harvesine formula yang bentuk persamaannya seperti berikut ini [9]:

$a=\sin ^{2}\left(\frac{\Delta \phi}{2}\right)+\cos \phi_{1} \cdot \cos \phi_{2} \cdot \sin ^{2}\left(\frac{\Delta \lambda}{2}\right)$

$c=2 \cdot \operatorname{atan} 2[\sqrt{a}, \sqrt{(1-a)}]$

$d=R \cdot c$

$\phi 1 \quad$ : Latitude titik pertama.

$\phi 2$ : Latitude titik kedua.

$\lambda 1$ : Longitude titik pertama.

$\lambda 2$ : Longitude titik kedua.

$\Delta \phi: \phi 1-\phi 2$

$\Delta \lambda: \lambda 1-\lambda 2$

$\mathrm{R} \quad$ : Radius Bumi $(6371 \mathrm{~km})$.

Hasil perhitungan jaraknya dapat dilihat pada lampiran 1.

\subsection{Pembuatan Algoritma Genetika Untuk TSP}

Algoritma Genetika yang dibuat bisa berbeda-beda walaupun masalah yang akan diselesaikan merupakan masalah yang sama. Perbedaan ini dikarenakan setiap orang mempunyai cara dan kreatifitas masing-masing dalam membuat Algoritma Genetika. Algoritma Genetika yang dibuat oleh penulis untuk menyelesaikan permasalahan TSP, sangat mungkin berbeda dengan Algoritma Genetika yang dibuat oleh orang lain, walaupun tujuanya sama yaitu untuk menyelesaikan TSP.

\section{Setting Parameters}

Parameter-parameter Algoritma Genetika yang digunakan oleh penulis kali ini adalah sebagai berikut:

\section{a) Crossover Probability}

Crossover Probability merupakan paramater yang menyatakan seberapa besar peluang sepasang orang tua akan melakukan perkawinan silang [3]. Rentang nilai untuk paramater ini adalah dari 0 sampai dengan 1 . Nilai yang akan 
Ekra Sanggala, Pengembangan Aplikasi Algoritma Genetika Berbasis Vba Excel Untuk Menyelesaikan Travelling Salesman Problem (Contoh Kasus: Tsp 20 Kota Di Rusia)

digunakan penulis untuk parameter ini adalah 0,75 .

b) Mutation Probability

Mutation Probability merupakan paramater yang menyatakan seberapa besar peluang suatu individu akan mengalami mutasi [3]. Rentang nilai untuk parameter ini adalah 0 sampai dengan 1. Nilai yang akan digunakan penulis untuk parameter ini adalah 0,1 .

c) Generation

Generation merupakan parameter yang menyatakan banyaknya generasi yang akan dihasilkan oleh Algoritma Genetika [3]. Batasan nilai untuk parameter ini adalah semua bilangan positif. Nilai yang akan digunakan penulis untuk parameter ini adalah 1000 .

d) Individual

Individual merupakan parameter yang menyatakan banyaknya individu yang akan hidup pada setiap generasi [3]. Batasan nilai untuk parameter ini adalah semua bilangan positif. Nilai yang akan digunakan penulis untuk parameter ini adalah 10 .

e) Survivor/Elite

Survivior/Elite merupakan parameter yang menyatakan banyaknya individu terbaik pada setiap generasi yang akan tetap hidup pada generasi berikutnya [3]. Rentang nilai untuk parameter ini adalah 0 sampai dengan nilai parameter individual dikurangi 1.Nilai yang akan digunakan penulis untuk parameter ini adalah 2 .

\section{Initialize Population}

Merupakan pembentukan individu-individu yang akan menjadi populasi awal atau populasi yang hidup di generasi 0 [3]. Karena jumlah kota pada TSP yang akan diselesaikan adalah 20 kota, maka setiap individu akan terdiri dari 21 gen. Gen 1 dan gen 21 akan berisi kota 1 (Moskwa) karena kota tersebut menjadi titik awal dan titik kembali dari rute yang terbentuk. Gen 2 sampai dengan gen 20 akan berisi dengan 19 kota lainnya. Cara random akan digunakan untuk memilih kota-kota yang akan mengisi gen 2 sampai dengan gen 20 pada individuindividu di populasi awal ini. Untuk contoh individu yang terbentuk dari cara random dapat dilihat pada gambar 1.

Gen

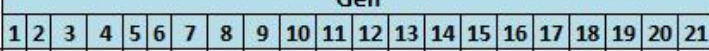

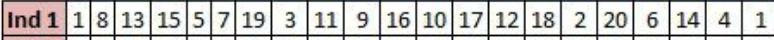

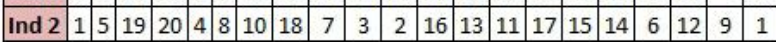

Gambar 1: Contoh Individu dari Cara Random

3. Crossover

Crossover merupakan perkawinan silang yang dilakukan oleh sepasang orang tua [3]. Cara crossover yang akan digunakan kali ini adalah onepoint crossover. Cara ini akan memilih secara random satu posisi gen yang akan menjadi posisi persilangan antara sepasang orang tua [3]. Pada Algoritma Genetika kali ini, setiap proses crossover akan menghasilkan dua anak. Dua anak yang dihasilkan dari crossover ini seringkali tidak memiliki gen yang lengkap, dan gen yang hilang pada satu anak akan menjadi gen ganda pada saudaranya. Oleh karena itu satu anak akan melakukan pertukaran gen ganda dengan saudaranya untuk saling melengkapi gen yang hilang. Proses pertukaran gen ganda yang akan digunakan kali ini adalah dengan memasangkan setiap gen ganda berdasarkan nomor gen ganda terkecil dengan nomor posisi gen terbesar. Untuk contoh one-point crossover ini dapat dilihat pada gambar 2 .

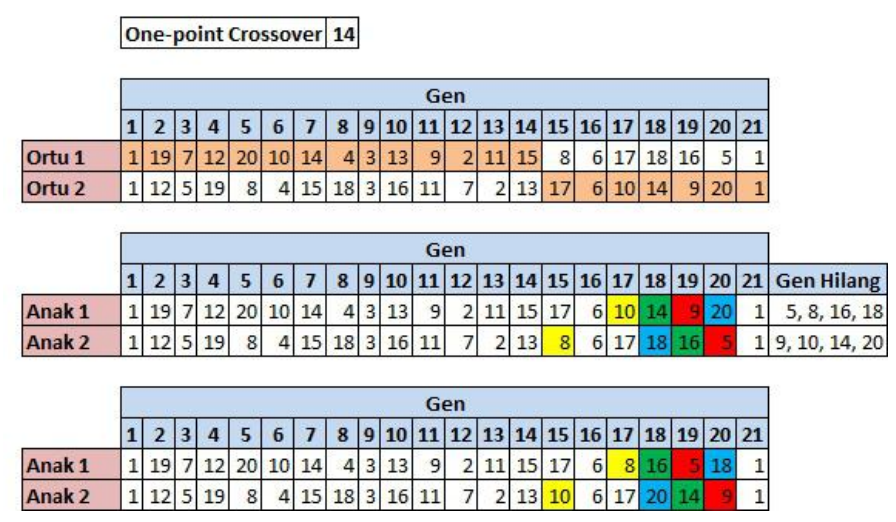

Gambar 2: Contoh One-point Crossover

\section{Mutation}

Mutation merupakan perubahan gen yang terjadi pada suatu individu [3]. Pada Algoritma Genetika kali ini, mutasi akan terjadi pada anak-anak yang dihasilkan dari crossover. Untuk kali ini cara mutasinya adalah dengan memilih sepasang gen secara random untuk bertukar tempat. Untuk contoh mutasi ini dapat dilihat pada gambar 3 .

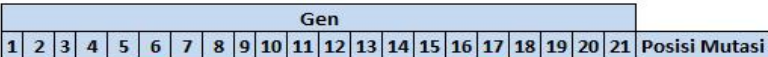

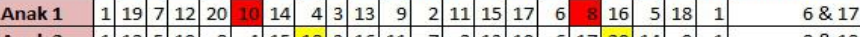

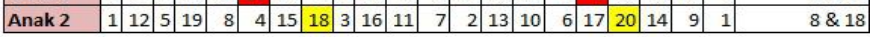

\begin{tabular}{|l|l|l|l|l|l|l|l|l|l|l|l|l|l|l|l|l|l|l|l|l|}
\hline 1 & 2 & 3 & 4 & 5 & 6 & 7 & 8 & 9 & 10 & 11 & 12 & 13 & 14 & 15 & 16 & 17 & 18 & 19 & 20 & 21 \\
\hline
\end{tabular}

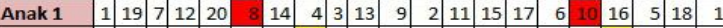

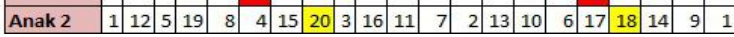

Gambar 3: Contoh Mutation

5. Genotype-phenotype Mapping

Genotype adalah susunan gen pada individu yang belum menjadi solusi untuk menyelesaikan permasalahan yang akan diselesaikan [3]. Genotype ini harus diterjemahkan menjadi phenotype agar dapat menjadi sebuah solusi [3]. Dikarenakan untuk kali ini susunan gen pada individu sudah dapat langsung menjadi solusi, maka tidak perlu dilakukan penerjemahan dari genotype ke phenotype.

6. Fitness

Fitness adalah sebuah nilai yang menyatakan seberapa baik kualitas suatu individu [3]. Pada Algoritma Genetika kali ini, semakin baik nilai fitness suatu individu maka semakin besar 
kemungkinannya individu tersebut akan terpilih untuk menjadi orang tua pada proses crossover. Untuk kali ini persamaan untuk menghitung nilai fitness adalah sebagai berikut:

$$
\begin{aligned}
& F_{i}=\max \left(L_{1}, L_{2}, \ldots ., L_{z}\right)-L_{i} \\
& F_{i}: \text { Nilai fitness individu ke }-i \\
& L_{i}: \text { Panjang rute individu ke }-i \\
& z: \text { Banyaknya individu pada populasi }
\end{aligned}
$$

Contoh nilai fitness dapat dilihat pada gambar 4.

\begin{tabular}{|l|l|l|l|l|l|l|l|l|l|l|l|l|l|l|l|l|l|l|l|l|l|l|}
\hline 1 & 2 & 3 & 4 & 5 & 6 & 7 & 8 & 9 & 10 & 11 & 12 & 13 & 14 & 15 & 16 & 17 & 18 & 19 & 20 & 21 & Length & Fitness \\
\hline
\end{tabular}

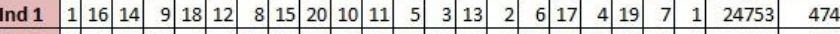

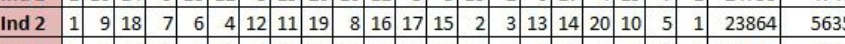

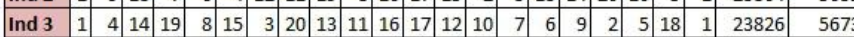

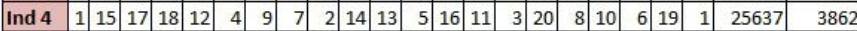

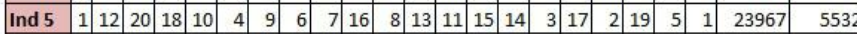

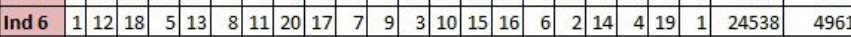

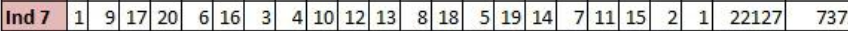

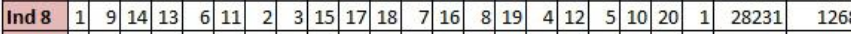

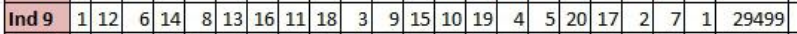

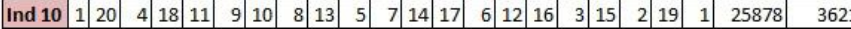

\section{Gambar 4: Contoh Nilai Fitness}

Agar lebih jelas, berikut ini adalah contoh perhitungan nilai fitness untuk individu 1.

$$
\begin{aligned}
& F_{i}=\max \left(L_{1}, \ldots . ., L_{10}\right)-L_{1} \\
& F_{1}=29499-24753 \\
& F_{1}=4746
\end{aligned}
$$

\section{Selection}

Selection adalah pemilihan sejumlah individu untuk digunakan pada proses selanjutnya [3]. Dikarenakan pada Algoritma Genetika kali ini jumlah individu pada setiap generasi adalah 10 individu dan jumlah individu yang menjadi survivor/elite adalah 2 individu, maka diperlukan 8 individu lagi yang akan hidup pada generasi selanjutnya. Pada Algoritma Genetika kali ini, proses pemilihan individu yang akan hidup pada generasi selanjutnya adalah dengan memilih semua anak yang dihasilkan pada setiap generasi. Oleh karena itu dikarenakan setiap crossover akan menghasilkan 2 anak, maka untuk menghasilkan 8 anak diperlukan 4 pasang orang tua atau 8 individu. Proses pemilihan 8 individu untuk menjadi orang tua ini dilakukan dengan cara Roulette Wheel, dimana individu yang memiliki nilai fitness lebih baik akan memiliki peluang lebih besar untuk terpilih [3].

\section{Termination}

Termination adalah terhentinya proses evolusi [3]. Pada Algoritma Genetika kali ini, termination akan terjadi jika proses evolusi sudah mencapai 1000 generasi.

\subsection{Pengembangan Aplikasi Berbasis VBA Excel}

Algoritma Genetika yang telah dibuat agar dapat menghasilkan solusi dengan cepat maka diterjemahkan ke dalam kode-kode program dan disimpan sebagai sebuah aplikasi. Penulisan kode-kode program ini dilakukan di VBA Excel.

\subsection{Penggunaan Aplikasi}

Setelah aplikasi selesai dibuat, maka aplikasi tersebut digunakan untuk menyelesaikan kasus TSP 20 Kota di Rusia.

\section{Hasil \& Pembahasan}

Pada bagian ini akan dibahas mengenai aplikasi yang telah dibuat menggunakan VBA Excel untuk menyelesaikan kasus TSP 20 Kota di Rusia. Karena aplikasi ini dibuat saat penulis sedang belajar bahasa Spanyol maka istilah-istilah dalam aplikasi ditulis dalam bahasa Spanyol, tapi para pembaca tidak perlu kuatir karena istilah-istilah tersebut akan disertakan bahasa Indonesianya. Kode program yang ditulis untuk menghasilkan aplikasi ini ada kurang lebih 567 baris. Jika kode tersebut ditampilkan pada tulisan ini tentu akan banyak menghabiskan tempat, oleh karena itu bagi pembaca yang memerlukan kodenya atau bahkan soft file dari aplikasi ini, dapat langsung menghubungi penulis melalui surat elektronik.

Pada aplikasi ini terdapat dua sheet yaitu sheet kotakota (Las Ciudades) dan sheet iterasi (Iteracion). Pada sheet kota-kota, kita harus memasukkan informasi sebagai berikut ini:

1. Nama dari 20 kota yang ada dalam kasus TSP 20 Kota di Rusia.

2. Latitude dan Longitude dari 20 kota yang ada dalam kasus TSP 20 Kota di Rusia.

3. Jarak antara setiap kota yang ada di kasus TSP 20 Kota di Rusia.

Tampilan dari sheet kota-kota setelah penulisan ketiga informasi tersebut dapat dilihat pada Lampiran 1.

Pada sheet iterasi, kita harus memasukkan informasi sebagai berikut ini:

1. Peluang Crossover (La Probabilidad de Crossover)

\begin{tabular}{|c|c|c|}
\hline La Probabilidad de Crossover & : & 0,75 \\
\hline La Probabilidad de Mutación & : & 0,1 \\
\hline La Generación & : & 1000 \\
\hline Los Individuos & : & 10 \\
\hline Supervivientes & : & 2 \\
\hline
\end{tabular}

2. Peluang Mutation (La Probabilidad de Mutación)

3. Banyaknya Generasi (La Generación)

4. Banyaknya Individu (Los Individuos)

5. Banyaknya Survivor/Elite (Supervivientes)

Tampilan dari sheet iterasi setelah penulisan kelima informasi tersebut dapat dilihat pada gambar 5 .

Gambar 5: Nilai-nilai Parameters pada Sheet Iterasi

Setelah memasukkan nilai-nilai parameters pada sheet iterasi maka perlu dilakukan penekanan tombol "Menghitung" (Calcular). Setelah tombol ini ditekan maka aplikasi akan mengeksekusi Algoritma Genetika yang telah dibuat.

Gambar 6 menampilkan individu-individu yang menjadi populasi awal yang hidup pada generasi 0 (Generación 0). Gambar 6 juga menampilkan panjang rute (La Distancia) untuk setiap individu. 


\begin{tabular}{|c|c|c|c|c|c|c|c|c|c|c|c|c|c|c|c|c|c|c|c|c|c|c|}
\hline Generacion 0 & 1 & 2 & 3 & 4 & 3 & 6 & 7 & $\gamma$ & 9 & 10 & 11 | & 12 & 13 & & 15 & 16 & 17 & 18 & 19 & 20 & & La Distancia $(\mathrm{Km})$ \\
\hline \begin{tabular}{|l|} 
Individuo - 1 \\
\end{tabular} & 1 & 16 & 14 & 9 & 18 & 12 & 8 & 15 & 20 & 10 & 11 & 5 & 3 & 13 & 2 & 6 & 17 & 4 & 19 & 7 & 1 & 24753 \\
\hline Individuo - 2 & 1 & 9 & 18 & 7 & 6 & 4 & 12 & 11 & 19 & 8 & 16 & 17 & 15 & 2 & 3 & 13 & 14 & 20 & 10 & 5 & 1 & 23864 \\
\hline Individuo - 3 & 1 & 4 & 14 & 19 & 8 & 15 & S & 20 & 13 & 11 & 16 & 17 & 12 & 10 & 7 & 6 & 9 & 2 & 5 & 18 & 1 & 23826 \\
\hline Individuo - 4 & 1 & 15 & 17 & 18 & 12 & 4 & 9 & 7 & 2 & 14 & 13 & 5 & 16 & 11 & 3 & 20 & 8 & 10 & 6 & 19 & 1 & 25637 \\
\hline Individuo - 5 & 1 & 12 & 20 & 18 & 10 & 4 & 9 & 6 & 7 & 16 & 0 & 13 & 11 & 15 & 14 & 3 & 17 & 2 & 19 & 5 & 1 & 23967 \\
\hline Individuo - 6 & 1 & 12 & 18 & 5 & 13 & 8 & 11 & 20 & 17 & 7 & 9] & 3 & 10 & 15 & 16 & 6 & 2 & 14 & 4 & 19 & 1 & 24538 \\
\hline \begin{tabular}{|l} 
Individuo - 7 \\
\end{tabular} & 1 & 9 & 17 & 20 & 6 & 16 & 3 & 4 & 10 & 12 & 13 & 8 & 18 & 5 & 19 & 14 & 7 & 11 & 15 & 2 & 1 & 22127 \\
\hline Individuo - 8 & 1 & 9 & 14 & 13 & 6 & 11 & 2 & 3 & 15 & 17 & 18 & 7 & 16 & 8 & 19 & 4 & 12 & 5 & 10 & 20 & 1 & 28231 \\
\hline-9 & & 12. & & 14 & & 13 & 16 & 11 & 18 & 3 & & 15 & 10 & 19 & 4 & 5 & 20 & 17. & 2 & 7) & 1 & 29499 \\
\hline Individuo - 10 & 1 & 20 & 4 & 18 & 11 & 9 & 10 & 8 & 13 & 5 & & 14 & 17 & 6 & 12 & 16 & 3 & 15 & 2 & 19 & 1 & 25878 \\
\hline
\end{tabular}

Gambar 6: Individu-individu pada Generasi 0

Gambar 7 menampilkan nilai fitness (La Conversion), nilai peluang (La Probabilidad), nilai akumulasi peluang (La Acumulación) dan ranking (El Ranking) dari individu-individu generasi 0 .

\begin{tabular}{|l|r|r|r|r|}
\hline Generacion 0 & La Conversion & La Probabilidad & La Acumulacion & El Ranking \\
\hline Individuo - 1 & 4746 & 0,111225685 & 0,111225685 & 6 \\
\hline Individuo - 2 & 5635 & 0,132059995 & 0,243285681 & 3 \\
\hline Individuo - 3 & 5673 & 0,132950551 & 0,376236232 & 2 \\
\hline Individuo -4 & 3862 & 0,090508554 & 0,466744786 & 7 \\
\hline Individuo -5 & 5532 & 0,129646121 & 0,596390907 & 4 \\
\hline Individuo-6 & 4961 & 0,116264354 & 0,712655261 & 5 \\
\hline Individuo-7 & 7372 & 0,172767753 & 0,885423014 & 1 \\
\hline Individuo - 8 & 1268 & 0,029716428 & 0,915139442 & 9 \\
\hline Individuo-9 & 0 & & 0,915139442 & 10 \\
\hline Individuo - 10 & 3621 & 0,084860558 & & 8 \\
\hline
\end{tabular}

Gambar 7: Nilai Fitness, Peluang, Akumulasi Peluang dan Ranking dari Individu-individu Generasi 0

Nilai peluang didapatkan dari persamaan berikut ini:

$$
P_{i}=\frac{F_{i}}{\sum_{j=1}^{Z} F_{j}}
$$

$P_{i}:$ Peluang individu $k e-i$

$F_{i}:$ Nilai fitness individu $k e-i$

$z$ : Banyaknya individu pada populasi

$F_{j}:$ Nilai fitness individu $k e-j$

Nilai akumulasi peluang didapatkan dari persamaan berikut ini:

$A_{i}=\sum_{j=1}^{i} P_{j}$

$A_{i}:$ Akumulasi peluang individu ke $-i$

$P_{j}:$ Peluang individu ke $-j$

Ranking ditentukan berdasarkan nilai fitness setiap individu, semakin baik nilai fitness maka semakin baik rankingnya.

Dari gambar 7 dapat dilihat bahwa Individu-3 (Individuo-3) dan Individu-7 (Individuo-7) akan menjadi survivor/elite karena menjadi 2 individu dengan nilai fitness tertinggi.

Gambar 8 menampilkan individu-individu yang terpilih untuk menjadi orang tua (Padre) pada proses crossover.

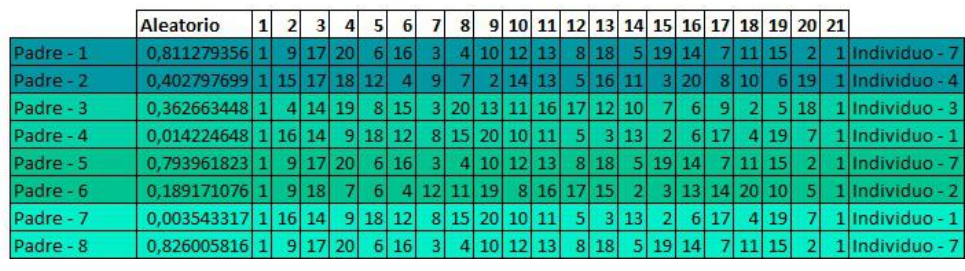

Gambar 8: Individu-individu yang Menjadi Orang Tua

Pemilihan individu untuk menjadi orang tua, dimulai dengan membangkitkan bilangan random (Aleatorio) untuk setiap orang tua. Nilai bilangan random ini antara 0 sampai dengan 1 . Nilai bilangan random para orang tua ini kemudian dibandingkan dengan nilai peluang akumulasi dari setiap individu. Individu yang mempunyai nilai peluang akumulasi terendah tetapi lebih besar atau sama dengan nilai bilangan random orang tua, maka dia akan terpilih untuk menjadi orang tua. Sebagai contoh dapat dilihat pada gambar 8 , orang tua pertama mempunyai nilai bilangan random 0,811279356 . Nilai peluang akumulasi terendah tetapi lebih besar atau sama dengan 0,811279356 adalah nilai peluang Individu-7 yaitu 0,885423014. Maka Individu-7 terpilih untuk menjadi orang tua pertama.

Gambar 9 menampilkan proses crossover yang dilakukan oleh para pasangan orang tua.

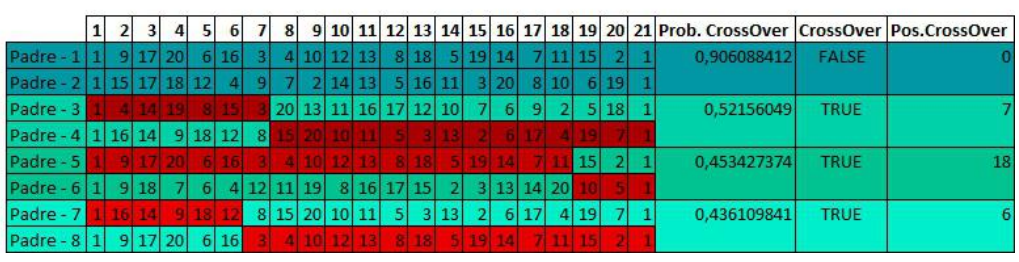

Gambar 9: Crossover para Orang Tua

Proses crossover dimulai dengan membangkitkan bilangan random (Prob. CrossOver) untuk setiap pasangan orang tua. Nilai bilangan random ini antara 0 sampai dengan 1. Nilai bilangan random setiap pasangan orang tua ini kemudian dibandingkan dengan nilai peluang crossover pada parameter. Pasangan orang tua yang mempunya nilai bilangan random lebih rendah atau sama dengan nilai peluang crossover maka akan melakukan crossover. Sebagai contoh dapat dilihat pada gambar 9, pasangan pertama (Padre-1 dan Padre-2) mempunyai nilai bilangan random 0,906088412. Nilai bilangan random tersebut lebih besar dari nilai peluang crossover $(0,75)$ maka pasangan tersebut tidak melakukan crossover. Karena pasangan pertama tidak melakukan crossover maka anak pertama akan memiliki susunan gen yang sama persis dengan ayahnya yaitu Padre-1 dan anak kedua akan memiliki susunan gen yang sama persis dengan ibunya yaitu Padre-2. Pasangan kedua (Padre-3 dan Padre-4) mempunyai nilai bilangan random 0,52156049 . Nilai bilangan random tersebut lebih kecil dari nilai peluang crossover $(0,75)$ maka pasangan tersebut melakukan crossover. Penentuan posisi crossover dilakukan secara random. Pasangan kedua ini mendapatkan posisi crossover-nya pada posisi gen no 7, sehingga gen no 1 sampai dengan no 7 dari anak pertama akan diambil dari ayahnya yaitu Padre-3, sedangkan gen no 8 sampai dengan no 21 dari 
anak pertama akan diambil dari ibunya yaitu Padre-4. Untuk anak keduanya, gen no 1 sampai dengan no 7 akan diambil dari ibunya yaitu Padre-4 dan gen no 8 sampai dengan no 21 akan diambil dari ayahnya yaitu Padre-3.

Gambar 10 menampilkan anak-anak yang dihasilkan dari crossover.

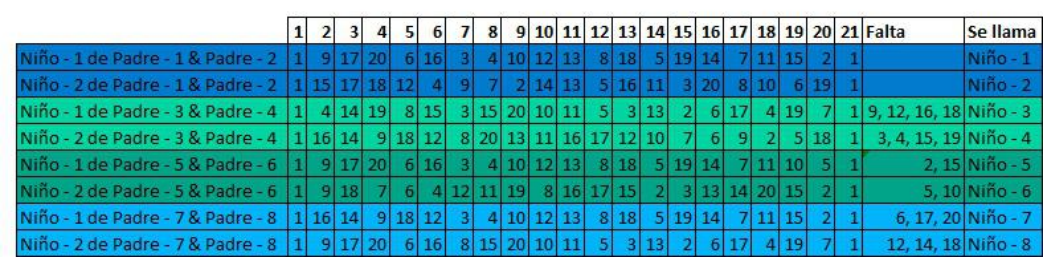

Gambar 10: Anak-anak Hasil Crossover

Dari gambar 10 dapat dilihat bahwa anak-anak yang merupakan hasil crossover mempunyai gen hilang. Sebagai contoh anak pertama dari pasangan kedua (Niño-1 de Padre-3 \& Padre-4) tidak memilikki gen 9, 12, 16 dan 18. Tapi gen-gen hilang tersebut menjadi gen ganda pada saudaranya yaitu anak kedua dari pasangan kedua (Niño-2 de Padre-3 \& Padre-4). Oleh karena itu mereka akan melakukan pertukaran gen ganda untuk saling melengkapi gen yang hilang. Pada gambar 10 juga dapat dilihat bahwa untuk mempermudah penyebutan anak-anak, maka mereka diberi nama (Se Llama) secara berurutan yaitu mulai dari Niño-1 sampai dengan Niño-8.

Gambar 11 menampilkan anak-anak yang telah memiliki gen secara lengkap.

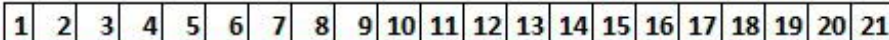

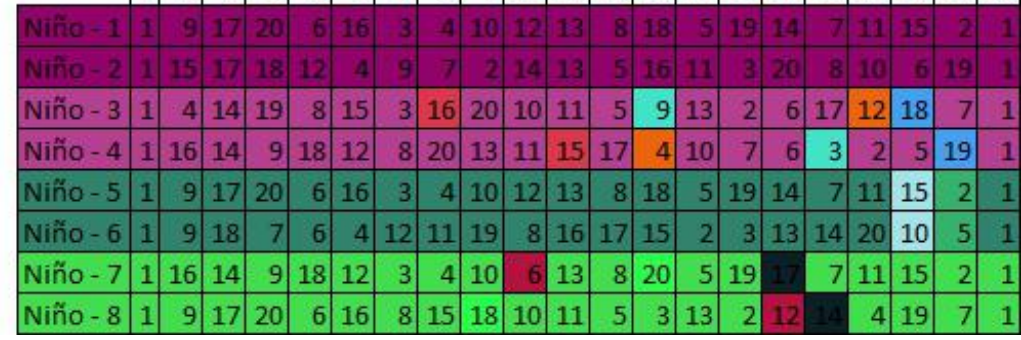

\section{Gambar 11: Anak-anak yang Memiliki Gen Secara Lengkap}

Dari gambar 11 dapat dilihat bahwa pada Algoritma Genetika yang telah dibuat, pertukaran gen ganda adalah dengan memasangkan setiap gen ganda berdasarkan nomor gen ganda terkecil dengan nomor posisi gen terbesar. Sebagai contoh, Niño-3 memiliki gen ganda pada gen 3 (posisi gen $7 \& 13$ ), 4 (posisi gen $2 \& 18$ ), 15 (posisi gen $6 \& 8$ ) dan 19 (posisi gen 4 \& 19), sedangkan saudaranya Niño-4 memilikki gen ganda pada gen 9 (posisi 4 \& 17), 12 (posisi gen $6 \& 13$ ), 16 (posisi gen 2 \& 11) dan 18 (posisi gen $5 \& 20$ ). Maka gen 3 posisi 13 dari Niño-3 akan berpasangan dengan gen 9 posisi 17 dari Niño-4, gen 4 posisi 18 dari Niño-3 akan berpasangan dengan gen 12 posisi 13 dari Niño-4, gen 15 posisi 8 dari Niño-3 akan berpasangan dengan gen 16 posisi 11 dari Niño-4 dan gen 19 posisi 19 dari Niño-3 akan berpasangan dengan gen 18 posisi 20 dari Niño-4.

Gambar 12 menampilkan anak-anak yang akan melakukan proses mutation.

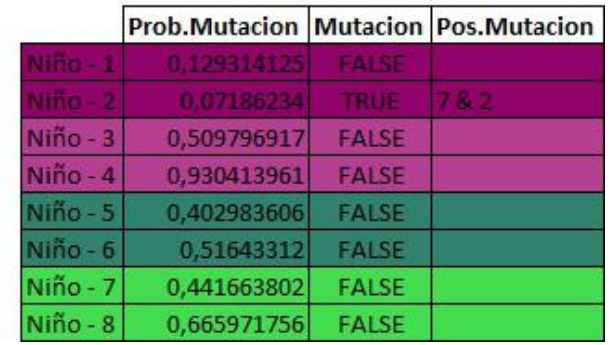

Gambar 12: Anak-anak yang akan melakukan proses Mutation

Proses mutation dimulai dengan membangkitkan bilangan random (Prob. Mutacion) untuk setiap anak. Nilai bilangan random ini antara 0 sampai dengan 1 . Nilai bilangan random setiap anak ini kemudian dibandingkan dengan nilai peluang mutation pada parameter. Anak yang mempunya nilai bilangan random lebih rendah atau sama dengan nilai peluang mutation maka akan melakukan Mutation. Sebagai contoh Niño-1 mempunyai bilangan random 0,129314125. Nilai bilangan random tersebut lebih besar dari nilai peluang mutation $(0,1)$ maka anak tersebut tidak melakukan mutation. Niño-2 mempunyai bilangan random 0,07186234 . Nilai bilangan random tersebut lebih kecil dari nilai peluang mutation $(0,1)$ maka anak tersebut akan melakukan mutation. Penentuan posisi mutation (Pos. Mutacion) akan dilakukan secara random. Niño-2 mendapatkan posisi mutation pada posisi 7 dan 2, maka gen pada posisi 7 dan 2 bertukar tempat.

Gambar 13 menampilkan anak-anak setelah proses mutation.

\begin{tabular}{|c|c|c|c|c|c|c|c|c|c|c|c|c|c|c|c|c|c|c|c|c|c|}
\hline & & & 3 & 4 & & & & & & 10 & 11 & 12 & 13 & 14 & 1 & 1 & 17 & 18 & 19 & 202 & \\
\hline กี้ก & & & 17 & 20 & 6 & 16 & & & 10 & 12 & 13 & & 18 & & 19 & 14 & & 11 & 15 & 2 & \\
\hline & & & 17 & 18 & 12 & 4 & 10 & & 2 & 14 & 13 & & 16 & 11 & & 20 & & 10 & & 19 & \\
\hline & & 4 & 14 & 19 & 8 & 15 & 3 & 16 & 20 & 10 & 11 & & & 13 & & & 17 & 12 & 18 & & \\
\hline $10-4$ & & 16 & 14 & & & 1 & & & 13 & 11 & 15 & 17 & & 10 & & & & & 5 & 19 & \\
\hline $0-5$ & & & 17 & 20 & 6 & 16 & 3 & & 10 & 12 & 13 & 1 & 18 & 5 & 19 & 14 & & 11 & 15 & 2 & \\
\hline 6 & & 9 & 18 & 7 & 6 & 4 & 12 & 11 & 19 & 8 & 16 & 17 & 15 & 2 & 3 & 13 & 14 & 20 & 10 & 5 & \\
\hline $0-7$ & 1 & 6. & 14 & 9 & 18 & 12 & 3 & 4 & 10 & 6 & 13 & 8 & 20 & 5 & 19 & 17 & 7 & 11 & 15 & 2 & \\
\hline iño- 8 & & & & & & & & & & 10 & 1 & & & 13 & & 12 & 14 & & & & \\
\hline
\end{tabular}

Gambar 13: Anak-anak Setelah Mutation

Kedelapan anak setelah proses mutation ini akan terpilih untuk hidup pada generasi 1. Ditambah dua survivor/elite maka pada generasi 1 akan hidup 10 individu. Gambar 14 menampilkan individu-individu yang hidup pada generasi 1 .

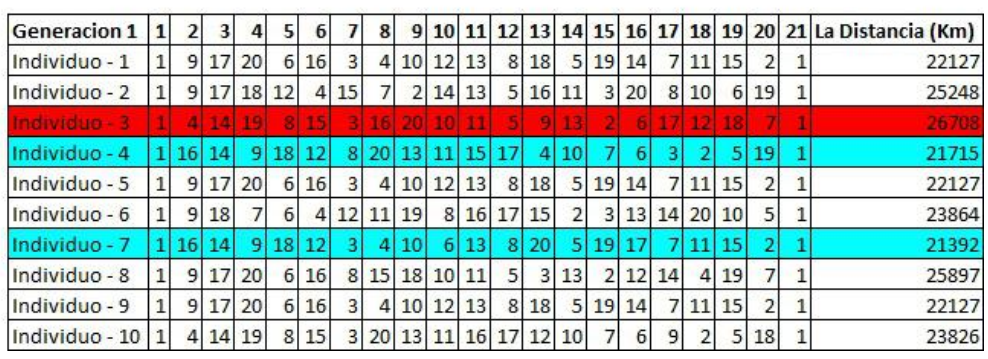

Gambar 14: Individu-individu pada Generasi 1 
Dari gambar 14 dapat dilihat bahwa Individu-1 sampai dengan Individu-8 merupakan Niño-1 sampai dengan Niño-8 dari generasi 0. Sedangkan individu-9 dan individu-10 merupakan survivor/elite dari generasi 0 , yaitu individu-7 dan individu-3.

Langkah-langkah pada Algoritma Genetika ini terus berulang dan akan berhenti saat tercapainya generasi ke1000. Waktu yang diperlukan untuk mencapai generasi 1000 adalah 12 menit 23 detik.

Gambar 15 menampilkan individu-individu yang hidup pada generasi 1000 .

\begin{tabular}{|c|c|c|c|c|c|c|c|c|c|c|c|c|c|c|c|c|c|c|c|c|}
\hline Seneracion 1000 & 1 & 2 & & 4 & 5 & 7 & 8 & & \begin{tabular}{l|l}
10 & 1 \\
\end{tabular} & 11 & 12 . & 1 & \begin{tabular}{l|l}
4 & 1 \\
\end{tabular} & 1 & \begin{tabular}{l|l|}
6 & 1 \\
\end{tabular} & 7 & 19 & 202 & $21 \mathrm{~L}$ & $\mathrm{a}(\mathrm{Km})$ \\
\hline ndividuo - 1 & 1 & 16 & \begin{tabular}{l|l}
9 & 1 \\
\end{tabular} & \begin{tabular}{l|l}
18 & 12 \\
2
\end{tabular} & $12 \quad 15$ & & 17 . & 19 & 5 & & 20 & 11 & 4 & 2 & 1 & 14 & 13 & 10 & 1 | & 14021 \\
\hline ndiv & 1 & 16 & 1 & \begin{tabular}{l|l}
18 & 12 \\
\end{tabular} & \begin{tabular}{l|l}
12 & 15
\end{tabular} & 6 & 13 & 19 & 5 & & 20 & 11 & \begin{tabular}{l|l}
4 & 1 \\
\end{tabular} & 10 & 7 & 14 & 17 & 2 & & 333 \\
\hline Indivi & 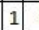 & 5 & 1 & \begin{tabular}{l|l}
18 & 12 \\
\end{tabular} & \begin{tabular}{l|l}
12 & 15
\end{tabular} & 10 & \begin{tabular}{|l|}
17 \\
17
\end{tabular} & 19 & 16 & of & 20 & 11 & \begin{tabular}{l|l}
4 & 1 \\
\end{tabular} & 10 & 7 & 14 & 13 & 2 & 1 & 086 \\
\hline Indivi & 1 & 16 & & \begin{tabular}{l|l}
18 & 12 \\
\end{tabular} & \begin{tabular}{l|l}
12 & 15 \\
\end{tabular} & 6 & 17 . & 19 & 5 & 8 & 20 & 11 & 41 & \begin{tabular}{l|l}
14 & 1 \\
\end{tabular} & 0 & 7| & 13 & 2 & 1 & 3347 \\
\hline Individuo - 5 & \begin{tabular}{|l|l}
1 & 1 \\
\end{tabular} & 16 & \begin{tabular}{l|l}
9 & 1 \\
\end{tabular} & \begin{tabular}{l|l}
18 & 12 \\
\end{tabular} & 1215 & 6 & \begin{tabular}{|l|l|}
17 & \\
\end{tabular} & $8 \mid$ & \begin{tabular}{l|l}
2 & 1 \\
\end{tabular} & 19 & 20 & 5 & $4 \mid 1$ & 10 & 7 & \begin{tabular}{l|l}
38 & 14 \\
\end{tabular} & 13 & 11 & 1 & 3162 \\
\hline divia & 1 & 16 & 14. 1 & t. & \begin{tabular}{l|l}
12 & 15 \\
\end{tabular} & & 17 & 19 & 5 & & & 11 & 4 & 10 & & & 13 & 2 & & 927 \\
\hline Indivic & 1 & 16 & \begin{tabular}{l|l}
9 & 1 \\
\end{tabular} & \begin{tabular}{l|l}
18 & 12 \\
\end{tabular} & \begin{tabular}{l|l}
12 & 5
\end{tabular} & & 15 . & 19 & 17 & 8 & 4 & 112 & 201 & 10 & 7 & 14 & 13 & 2 & 1 & 2478 \\
\hline Indiv & \begin{tabular}{l|l}
1 & 1 \\
\end{tabular} & 16 & \begin{tabular}{l|l}
9 & 1 \\
\end{tabular} & \begin{tabular}{l|l|}
18 & 12 \\
\end{tabular} & \begin{tabular}{l|l|}
12 & 15 \\
\end{tabular} & 6 & 17 & 19 & 5 & & 20 & 11 & 41 & 10 & 8 & 14 & 13 & 2 & & 4816 \\
\hline ndiv & \begin{tabular}{|l|l}
1 & 1 \\
\end{tabular} & 16 & \begin{tabular}{l|l}
9 & 1 \\
\end{tabular} & \begin{tabular}{l|l}
18 & 12 \\
\end{tabular} & $12 \quad 15$ & 6 & 17 & 19 & 5 & & 20 & 11 & 4. & 10 & 7 & 14 & 13 & 2 & & 0792 \\
\hline ndividuo - 10 & \begin{tabular}{l|l}
1 & 1 \\
\end{tabular} & & \begin{tabular}{l|l}
9 & 1 \\
\end{tabular} & & & & & & & & & & & & & 14 & & & & 10792 \\
\hline
\end{tabular}

Gambar 15: Individu-individu pada Generasi 1000

Dari gambar 15 dapat dilihat bahwa Individu-9 dan Individu-10 merupakan individu terbaik pada generasi 1000. Dengan demikian solusi dari TSP 20 Kota di Rusia ini mengikuti susunan gen dari Individu-9 atau Individu10, yaitu 1-16-9-18-12-15-6-17-19-5-8-20-11-4-10-7-314-13-2-1. Maka urutan kota-kota yang dikunjungi adalah Moskwa - Voronezh - Rostov - Krasnodar Volgograd - Saratov - Samara - Tolyatti - Ulyanovsk Nizhniy Novgorod - Kazan - Izhevsk - Ufa Yekaterinburg - Chelyabinks - Omsk - Novosibirsk Krasnoyarsk - Perm - Saint Petersburg - Moskwa dengan panjang rute $10.792 \mathrm{Km}$. Solusi yang diperoleh ini, tidak selalu sama pada setiap pengeksekusian Algoritma Genetika. Setiap pengeksekusian Algoritma Genetika dapat memberikan solusi yang berbeda-beda.

\section{Kesimpulan}

Aplikasi ini cocok digunakan untuk keperluan latihan dan sebagai media pembelajaran untuk memahami langkah-langkah pada Algoritma Genetika.

Penelitian ini bisa menjadi dasar untuk pengembangan aplikasi yang cocok untuk penyelesaian kasus TSP yang lebih komplek, dan juga untuk keperluan industri. Satu hal yang perlu diperhatikan untuk penelitian selanjutnya adalah kemampuan komputasi yang lebih baik, yang tentunya memerlukan teknik pemrograman yang lebih tinggi. Hal lainnya yang perlu diperhatikan adalah User Interface yang lebih baik, sehingga lebih memudahkan para penggunanya.

\section{Daftar Pustaka}

[1] A. Philip, A.A. Taofiki, and O. Kehinde, A Genetic Algorithm for Solving Travelling Salesman Problem, International Journal of Advanced Computer Science and Applications, Vol.2, No.1 January 2011.

[2] M. Catana, C. Neagu, and S. Tonoiu, Scheduling of Job-Shop Production Projects with Microsoft Office Excel, Academic Journal of Manufacturing Engineering, Vol.7, pp.31-36, April 2009.

[3] O. Kramer, Genetic Algorithm Essentials, Springer, Switzerland, 2017.

[4] D.L. Applegate, R.E. Bixby, V. Chvatal, and W.J. Cook, The Traveling Salesman Problem A Computational Study, Princeton University Press, New Jersey, 2006.

[5] A. Katz, Beginning Microsoft Excel 2010, Apress, New York, 2010.

[6] J. Walkenbach, Excel 2010 Power Programming with VBA, Wiley Publishing, Indiana, 2010.

[7] B. Jelen and T. Syrstad, VBA and Macros for Microsoft Excel, Sams Publishing, Indiana, 2004.

[8] https://download.geonames.org/export/dump/

[9] https:/www.omncalculator.com/other/azimuth 